\title{
Legal Protection For Medical Traditional Treatment Based On Empirical The Government Act No. 103/2014 On Traditional Health Services In The District Semarang
}

\author{
Perlindungan Hukum Bagi Penyehat Pengobatan Tradisional Empiris Berdasarkan Peraturan \\ Pemerintah Nomor 103 Tahun 2014 Tentang Pelayanan Kesehatan Tradisional Di Kabupaten \\ Semarang \\ Erny Amperawati; Hermawan Pancasiwi and Hari Pudjo Nugroho \\ email:wira_medika@yahoo.com \\ Master of Law Science \\ Concentration of Health Law \\ Soegijapranata Catholic University of Semarang
}

\begin{abstract}
The purpose of this study was to know and understand the provisions of legal protection for medical traditional treatment the empirical basis of Law and Act Government No. 103/2014; authority of the local government of Semarang Regency in applying the legal protection aspect for the health of traditional medicine; and health strategies in Semarang Regency in integrating traditional medicine with standardization of health services in accordance with applicable Laws and Regulations.

Research this use method qualitative with approach juridical sociological. Specification from research this is research descriptive. Method analysis of data on research this use qualitative data analysis.
\end{abstract}

The results of this study are: (1) Interest use treatment Traditionally, not also inseparable from the increase complexity illness society, of accompanied with needs cost further treatment Great. As a result, treatment traditional back ogled as wrong one alternative problem solving. Supported with ingredients raw nature provided, as well as existence knowledge hereditary from system treatment Traditionally, the interest community will utilization treatment traditional permanent there is and increasingly increased; (2) The authority government inprotection law service health traditional could reviewed from function government based on protection on law. There is three kind of form protection law government that is as maker legislation, implementing Constitution and as supervisor legislation. As maker legislation, overnment authorized make something regulations governing with concrete about service health traditional. Health Law set field health onthorough but no Specific in set service health traditional. Setting more special arranged in PP 103/2014 as regulations implementing the Health Law; and (3) Services Health Traditional in run activities with aim for treat or cure person pain, close possibility for looking for benefit economical anyway. So on general provider services service health traditional could it says as perpetrators businesses engaged in field service-services health, namely service health traditional. This corresponding with definition perpetrators business in Article 1 paragraph 3 of Law Protection Consumers meaningful wide. Understanding perpetrators significant effort large the will make it easy consumer in demanding replace loss when there problems law. Rules Government No. 103/2014 only give permission on two expertise only on healthier treatment traditional Empirical.

Keywords : Legal Protection, Empirical Medical Traditional Treatment Services Health Traditional 


\section{A. Latar Belakang}

Kesehatan adalah merupakan hak dasar yang perlu dipenuhi dalam taraf hidup masyarakat. Pasien juga memiliki hak untuk mendapatkan pelayanan kesehatan. Hak untuk mendapatkan pelayanan kesehatan merupakan bentuk pemenuhan Hak Asasi Manusia (HAM) di bidang kesehatan. ${ }^{1}$

Pembangunan kesehatan didalam Undang -Undang Kesehatan 2009 dan pada Peraturan Pemerintah No 72 thn 2012 tentang Sistem Kesehatan Nasional dilaksanakan melalui berbagai upaya dalam bentuk pelayanan kesehatan tradisional pada Fasilitas Pelayanan Kesehatan. ${ }^{2}$

Dari beberapa literatur WHO, disebutkan bahwa traditional medicine memiliki arti yang sama dengan Complementary-Alternative Medicine (CAM). Negara-Negara yang menggunakan istilah pengobatan tradisional biasanya merupakan negara yang lebih banyak mengembangkan pelayanan bermetode empiris. Di Indonesia, istilah ini digunakan untuk pengobatan tradisional, alternatif, atau komplementer. Berdasarkan metode yang digunakan, kementrian kesehatan mengklasifikasi pengobatan tradisional ke dalam dua golongan yaitu: pengobat tradisional (battra) keterampilan manual, battra keterampilan alat/teknologi, battra ramuan. ${ }^{3}$

Menurut Peraturan Pemerintah Tahun 2014 tentang Pelayanan Kesehatan Tradisional seorang pengobat tradisional harus mempunyai Surat Izin Praktik Tenaga Kesehatan Tradisional. Pasal 1 angka 5 dalam Peraturan Pemerintah tentang Pelayanan Kesehatan dinyatakan bahwa:

Surat Terdaftar Penyehat Tradisional yang selanjutnya disingkat STPT adalah bukti tertulis yang diberikan kepada penyehat tradisional yang telah mendaftar untuk memberikan Pelayanan Kesehatan Tradisional Empiris.

Di Kabupaten Semarang, praktek pengobatan tradisional pun semakin meningkat dari tahun ke tahun. Menurut data Dinas Kesehatan Kabupaten Semarang dalam kurun waktu empat tahun terakhir, mulai tahun 2013-2016 terjadi peningkatan jumlah pengobatan tradisional terdaftar. meskipun tidak begitu signifikan. Dinas Kesehatan setempat dari yang dapat dilihat pada tahun 2013-2016 dengan jumlah peningkatan yang tidak begitu besar. Sayangnya, dari data yang diacu belum dapat dilihat secara lengkap pendataan mengenai jumlah total batra yang dibina oleh Dinas kesehatan setempat. Hal ini menandakan bahwa pelaporan/pendataan pada tingkat kabupaten masih belum dilaksanakan dengan baik.

\begin{tabular}{|l|c|c|c|c|}
\hline Tahun & 2013 & 2014 & 2015 & 2016 \\
\hline Jumlah total Batra & 139 & - & 144 & 148 \\
\hline Jumlah total Batra yang dibina & 133 & 137 & - & - \\
\hline
\end{tabular}

Sumber : Data Dinas Kesehatan Kabupaten Semarang 2013-2016

\footnotetext{
1 WHO, 2009, Manajemen Pelayanan Kesehatan Primer, Ed.2, Jakarta: Penerbit Buku Kedokteran, hlm. 29
} 
Pendataan Dinas Kesehatan di wilayah Kabupaten Semarang merupakan salah satu implementasi penerapan Peraturan Pemerintah tentang Pelayanan Kesehatan Tradisional, mengenai tanggungjawab dan wewenang pemerintah daerah kabupaten/kota. Untuk itu pemerintah daerah dalam hal ini memiliki peran dalam rangka melayani pendataan pengobatan tradisional sesuai dengan syarat dan standarisasi yang telah ada atau ditentukan. Oleh karenanya, penelitian ini dilakukan untuk memberi gambaran/penjelasan konkret mengenai bagaimana skema payung hukum atau perlindungan hukum yang telah diatur dalam Undang-Undang Dasar 1945 bagi para penyehat pengobatan tradisional empiris.

Seiring dengan meningkatnya jumlah pengobatan tradisional setiap tahunnya di Kabupaten Semarang maka kiranya banyak pula praktek pengobatan tradisional yang harus melakukan penyesuaian dalam memenuhi standar dan syarat yang telah diatur dalam Perundang-undangan tersebut. Lantas, bagaimana penyehat dalam praktek pengobatan tradisional harus menyesuaikan praktek pengobatannya.

Menurut Pasal 1 angka 1 Permenkes no 61 th 2016 tentang Pelayanan Kesehatan Tradisional Empiris bahwa:

Pelayanan Kesehatan Tradisional Empiris, adalah penerapan kesehatan tradisional yang manfaat dan keamanannya terbukti secara empiris.

Sesuai dengan Peraturan Pemerintah No 103 th 2014 tentang Pelayanana Kesehatan memuat peraturan yang mengatur tentang tanggung jawab dan wewenang pemerintah daerah terkait dengan penyelenggaraan pelayanannya. Dalam penyelenggaraan pelayanan termuat ketentuan-ketentuan yang berlaku, dimana didalamnya mengandung hak dan kewajiban. Berdasarkan studi pendahuluan didapatkan data bahwa beberapa penyelenggara/penyehat merasa kewenangannya dibatasi. Sehingga peneliti tertarik untuk meneliti tentang pelaksanaan dan perlindungan hukum dalam pelayanan kesehatan tradisional empiris di Kabupaten Semarang Propinsi Jawa Tengah. Dengan judul tesis:

"Perlindungan Hukum Bagi Penyehat Pengobatan Tradisional Empiris Berdasarkan Peraturan Pemerintah Nomor 103 Tahun 2014 Tentang Pelayan Kesehatan Tradisional Di Kabupaten Semarang"

\section{B. Perumusan Masalah}

Berdasarkan Uraian dan latar belakang diatas, penelitian ini lebih berfokus pada permasalahan yang akan dikaji mengenai perlindungan hukum terhadap penyehat pengobatan tradisional empiris berdasarkan Peraturan Pemerintah Nomor 103 Tahun 2014 tentang Pelayanan Kesehatan Tradisional di Kabupaten Semarang sebagai berikut:

1. Bagaimana pengaturan perlindungan hukum bagi penyehat pengobatan tradisional empiris berdasarkan UU Nomor 36 Tahun 2009 tentang Kesehatan dan PP Nomor 103 Tahun 2014 tentang Pelayanan Kesehatan Tradisional?

2. Bagaimana peran Pemerintah Daerah Kabupaten Semarang dalam melaksanakan wewenangnya menerapkan aspek perlindungan hukum bagi penyehat pengobatan tradisional empiris?

3. Bagaimana penyehat tradisional menerapkan ketentuan perundang-undangan terkait dengan praktek pengobatan tradisionalnya di Kabupaten Semarang? 


\section{Metode Penelitian}

\section{Metode Pendekatan}

Penelitian ini menggunakan metode kualitatif dengan pendekatan yuridis sosiologis, yaitu suatu studi yang dapat membahas aspek yuridisnya sekaligus membahas dari aspek-aspek sosial yang melingkupi gejala hukum tertentu. ${ }^{2}$ Aspek yuridis dikaitkan dengan peraturan perundang-undangan yang berlaku, sedangkan aspek sosiologis dikaitkan dengan faktor-faktor di luar hukum yang berhubungan dengan praktik penyehat dalam pelayanan kesehatan tradisional.

\section{Spesifikasi Penelitian}

Spesifikasi dari penelitian ini adalah penelitian deskriptif yang akan dilakukan dengan cara memaparkan tentang masalah hokum kesehatan dengan menjelaskan berbagai inventarisasi hokum positif dalamperlindungan hokum bagi penyehat pengobatan empiris serta penerapan perlindungan hokum oleh pemerintah

\section{Jenis data}

Data yang digunakan dalam penelitian ini diantaranya adalah:

a. Data primer, yakni data yang dikumpulkan oleh peneliti melalui wawancara kepada informan dan narasumber yang terkait.

b. Data Sekunder, yakni data yang didapatkan dari dokumen instansi terkait dan juga literatur. Diantaranya adalah beberapa bahan hukum:

1) Bahan hukum primer: Bahan hukum yang mengikat seperti undang-undang dan juga peraturan pemerintah yang secara tertulis telah didokumentasikan ke dalam suatu bahan hukum yang mengikat

2) Bahan hukum sekunder adalah bahan hukum yang memberikan penjelasan terhadap bahan-bahan hukum primer berupa buku, jurnal, mengenai perlindungan hukum bagi penyehat tradisional empirik atau yang disebut juga sebagai literatur.

3) Bahan hukum tersier adalah bahan hukum yang memberikan petunjuk bermakna terhadap bahan hukum primer dan sekunder.

\section{Metode Pengumpulan Data}

Dari jenis data di atas, maka penelitian ini mengumpulkan data primer dengan melakukan berbagai aktivitas observasi partisipan serta wawancara mendalam terhadap berbagai narasumber. yang dipilih dengan teknik purposive sampling, dimana peneliti dapat memilih informan kunci sebagai penunjuk untuk memilih narasumber lainnya dengan tujuan untuk mendapatkan data tertentu yang berkaitan dalam penelitian terhadap perlindungan hukum bagi penyehat pengobatan tradisionsl.

Adapun informan yang dimaksud di dalam penelitian adalah para penyehat pengobatan tradisional empiris baik yang terdaftar maupun yang tidak terdaftar sebagai binaan oleh Dinas Kesehatan Pemerintah Daerah Kabupaten Semarang, serta para pasien pengguna praktek pengobatan tradisional empiris. Sementara itu narasumber yang dimaksud dalam penelitian ini adalah pejabat maupun pegawai di Dinas Kesehatan Kabupaten Semarang yang memiliki informasi dan pengetahuan mengenai pelayanan kesehatan pengobatan tradisional serta 3 (tiga) orang

${ }^{2}$ Agnes Widanti, dkk, 2009. Petunjuk Penulisan Usulan Penelitian Dan Tesis. Semarang: Penerbit UNIKA Soegijapranata, hlm. 7 
terapis/penyehat tradisional empiris. Selain itu, untuk jenis data sekunder didapatkan melalui studi pustaka dengan mengumpulkan dan mempelajari dokumen-dokumen serta literatur yang menunjang analisis data.

\section{Metode Analisis Data}

Data penelitian ini menggunakan analisis data kualitatif, dengan menguraikan datadatanya secara naratif yang diperoleh dari data primer dan sekunder. ${ }^{3}$ Data yang sudah didapatkan akan dilakukan analisis secara kualitatif, yaitu analisis yang tidak menggunakan parameter statistik, untuk mengetahui pelaksanaan praktik pelayanan kesehatan tradisional empiris di Kabupaten Semarang menurut peraturan perundangundangan.

\section{Hasil Penelitian dan Pembahasan}

Sesusi dengan rencana penenilian ini,yang penulis lakukan di Wilayah Kabupaten Semarang,untuk mengetahui perlindungan hukum pengobat tradisional yang banyak terdapat dikota Ungaran dengan berbagai ketrampilan secara turun temurun.

Adapun nara sumber diperoleh dari Pejabat bidang pelayanan Dinas Kesehatan Kabupaten Semarang,Ketua Forum Hatrra Kabupaten Semarang dan Pengobat Tradisional .

\section{Pengaturan Perlindungan Hukum bagi Penyehat Pengobatan Tradisional Empiris Berdasarkan Undang-undang Nomor 36 Tahun 2009 dan Peraturan Pemerintah Nomor 103 Tahun 2014 Tentang Pelayanan Kesehatan}

Kesehatan adalah kebutuhan dasar bagi setiap orang. Undang-Undang Kesehatan th 2009 Pasal 1 Ayat (1) mendefinisikan bahwa, Kesehatan adalah keadaan sehat, baik secara fisik, mental, spritual maupun sosial yang memungkinkan setiap orang untuk hidup produktif secara sosial dan ekonomis.

Sumber pengobatan di dunia mencakup tiga sektor yang saling terkait yaitu pengobatan rumah tangga atau pengobatan sendiri, pengobatan tradisional dan pengobatan medis yang dilakukan oleh perawat, dokter, Puskesmas atau Rumah Sakit. ${ }^{4}$

Berdasarkan Sensus Sosial Ekonomi penduduk di Indonesia, yang menggunakan pengobatan tradisional mengalami peningkatan yaitu 15,04\% pada tahun 1999 menjadi 30,24\% tahun 2001, tahun 2002 turun menjadi 29,73\%. Pada tahun 2003-2006 mengalami kenaikkan 30,67\% tahun 2003, 32,87\% tahun 2004, 35,25\% tahun 2005 dan 38,30\% pada tahun 2006. Berdasarkan hasil Survey Sosial Ekonomi Nasional (SUSENAS) tentang penggunaan pengobatan tradisional meningkat dari tahun ke tahun (digunakan oleh 40\% penduduk Indonesia). Pada tahun 2010 penggunaan pengobatan tradisional meningkat menjadi 45,17\% dan tahun 2011 menjadi 49,53\%.5

\footnotetext{
${ }^{3}$ Agnes Widanti, Loc.cit, hlm. 7

4 Masitah Effendi, 2012, Pemanfaatan Sistem Pengobatan Tradisional (BATTRA) di Puskesmas Gundih Surabaya. [Skripsi]. Surabaya: Fakultas IImu Sosial IImu Politik Universitas Airlangga

5 Dewi Andika Rahayu, 2012, Faktor-Faktor yang Berhubungan dengan Pemilihan Pengobatan Tradisional di Wilayah Kerja Puskesmas Muara Siberut Kecamatan Siberut
} 
Sebelumnya dicabut pelaksanaan pengobatan tradisional diatur dalam Keputusan Menteri Kesehatan Nomor 1076/Menkes/SK/VII/2003 tentang Penyelenggaraan Pengobatan Tradisional bahwa klasifikasi dan jenis pengobatan tradisional terbagi menjadi 4 yaitu Pengobatan tradisional keterampilan; pengobatan tradisional ramuan; pengobatan tradisional pendekatan agama; dan pengobatan tradisional pendekatan supranatural. Maka di tahun 2014, Pemerintah Republik Indonesia menimbang bahwa untuk melaksanakan ketentuan dalam Pasal 59 ayat (3) mengenai Pelayanan Kesehatan tradisional didalam Undang-Undang Nomor 36 Tahun 2009 tentang Kesehatan, perlu menetapkan Peraturan Pemerintah Nomor 103 Tahun 2014 tentang Pelayanan Kesehatan Tradisional untuk mencabut Keputusan Menteri Kesehatan Nomor 1076/Menkes/SK/VII/2003 tentang Penyelenggaraan Pengobatan Tradisional dan Peraturan Menteri Kesehatan Nomor 1109 Tahun 2007 tentang Penyelenggaraan Pengobatan Komplementer Alternatif, yang sudah dikeluarkan sebelumnya.

Terdapat perubahan dalam Peraturan Pemerintah Republik Indonesia No 103 Tahun 2014 tentang Pelayanan Kesehatan Tradisional, diantaranya jenis pelayanan kesehatan tradisional yang meliputi Pelayanan Kesehatan Tradisional Empiris, Pelayanan Kesehatan Tradisional Komplementer, dan Pelayanan Kesehatan Terintegrasi. Kemudian pemberian pelayanan kesehatan tradisional yang sebelumnya disebut pengobat tradisional, kini dilakukan oleh penyehat tradisional untuk pelayanan kesehatan tradisional empiris dan tenaga kesehatan tradisional untuk pelayanan kesehatan komplementer serta pelayanan kesehatan tradisional terintegrasi.

Sebelum diundangkan, Peraturan Pemerintah Tahun 2014, Keputusan Menteri Kesehatan Nomor 1076/Menkes/SK/VII/2003 tentang Penyelenggaraan Pengobatan Tradisional dan Permemkes Nomor 1109 Tahun 2007 tentang Penyelenggaraan Pengobatan Komplementer Alternatif digunakan sebagai pedoman hingga dikeluarkan Peraturan Pemerintah Nomor 103 Tahun 2014 tentang Pelayanan Kesehatan Tradisional.

Sebagai turunan dari kebijakan mengenai Pengobatan tradisional dan Pengobatan Komplementer Alternatif, Kota Semarang mengeluarkan kebijakan berupa peraturan yang lebih mendasar di tingkat kota yaitu berupa surat keputusan kepala Dinas Kesehatan Kota mengenai pembentukan Tim Pembina Pengobat Tradisional (Batra) Kota Semarang yang dikeluarkan tahun 2004 kemudian diperbaharui di tahun 2012. Walau begitu, surat keputusan ini isinya belum serta merta mewakili kebijakan pemerintah yang digunakan sebagai pedoman sebelumnya.

Berdasarkan hasil penelitian yang penulis lakukan di Dinas Kesehatan Kabupaten Semarang, ${ }^{6}$ diperoleh data mengenai penyehat tradisional yang terdaftar di Dinas Kesehatan Kabupaten Semarang adalah tahun 2014 ada sejumlah 54 penyehat tradisional, tahun 2015 sebanyak 62 penyehat tradisional, tahun 2016 sebanyak 58 penyehat tradisional dan pada tahun 2017 sebanyak 61 penyehat tradisional yang sudah terdaftar, sedangkan penyehat tradisional yang belum terdaftar masih banyak yakni sekitar 50 penyehat tradisional.

Selatan Kabupaten Kepulauan Mentawai Tahun 2012.Mentawai.[Jurnal]. Padang: Fakultas Kesehatan Masyarakat.

${ }^{6}$ Penelitian di Dinas Kesehatan Kabupaten Semarang pada tanggal 14 April 2017 
Berdasarkan hasil wawancara penulis dengan Nur Misbah,7 selaku pengelola dan pelaku penyehat pengobatan tradisional pada Klinik As-Salam Apacinti Kabupaten Semarang, diperoleh keterangan bahwa beliau merasa tidak nyaman karena merasa dibodohi dengan adanya PP No 103 Tahun 2014 tentang Pelayanan Kesehatan Tradisional dan beliau menyimpulkan bahwa dengan adanya Peraturan Pemerintah Nomor 103 Tahun 2014 tentang Pelayanan Kesehatan Tradisional tersebut pengobatan tradisional tidak akan maju. Sebagai contoh, adanya larangan bekam basah, karena beranggapan bahwa bekam itu adalah sunnah, maka larangan terhadap penyehat tradisional bekam yang bukan tenaga kesehatan akan diabaikan. Untuk yang akan datang sekiranya pelaku penyehat tradisional khususnya bekam yang bukan tenaga kesehatan tetap akan melakukan praktek bekam meski tidak berijin.

Menurut Nur Misbah, ${ }^{8}$ selaku pengelola dan pelaku penyehat pengobatan tradisional pada Klinik As-Salam Apacinti Kabupaten Semarang, dengan adanya Peraturan Pemerintah 2014 tentang Pelayanan Kesehatan Tradisional ruang gerak penyehat pengobatan tradisional merasa dipersempit. Intinya, sebagai penyehat tradisional empiris adalah menolong orang dengan berbagai ketrampilan dan metode pengobatan. Harapan sebagai penyehat pengobatan tradisional memohon untuk meninjau kembali Peraturanini, tidak hanya bagi i penyehat akan tetapi juga sebagai pengobat tradisional.

Fakta bahwa tingginya minat masyarakat pada pengobatan tradisional tergambar pada Riset Kesehatan Dasar (RISKESDAS) 2010, yaitu tercatat 59,12\% penduduk Indonesia menggunakan ramuan tradisional jamu untuk memelihara kesehatan, dan 95,60\% diantaranya mengaku ramuan tradisional yang digunakan sangat bermanfaat bagi kesehatan. ${ }^{9}$

Menurut Dirjen Bina Kesehatan Masyarakat Kementerian Kesehatan, pengobat tradisional di Indonesia yang tercatat seluruhnya sejumlah 280.000 pengobat dengan 30 keahlian/ spesialisasi. Meskipun demikian, hingga saat ini baru sedikit Rumah Sakit atau dokter yang mau memadukan layanan pengobatan tradisional dengan kedokteran modern. Sampai jelang akhir 2013, baru 529 Puskesmas dan 84 Rumah Sakit yang menjalankan program pelayanan kesehatan tradisional. Pada tahun 2014, diantara 2.083 Rumah Sakit dan 9.510 Puskesmas, Kementerian Kesehatan mentargetkan lebih banyak pelayanan kesehatan yang menjalankan, yaitu sebanyak 70 Rumah Sakit dan lebih dari 500 puskesmas yang tersebar di Indonesia dapat memberi pelayanan alternative dan komplementer. Fakta lain juga menyatakan bahwa dari 2.083 rumah sakit yang ada di Indonesia, hanya 55 rumah sakit saja yang melaksanakan pelayanan kesehatan tradisional, alternatif dan komplementer. ${ }^{10}$ Hal tersebut

\footnotetext{
${ }^{7}$ Wawancara dengan Nur Misbah, selaku Pengelola dan Pelaku Penyehat Tradisional pada Klinik As-Salam Apacinti Kabupaten Semarang, pada tanggal 14 April 2017

8 Wawancara dengan Nur Misbah, selaku Pengelola dan Pelaku Penyehat Tradisional pada Klinik As-Salam Apacinti Kabupaten Semarang, pada tanggal 14 April 2017

9 Layanan Tradisional Diterapkan di 70 RD. http://pointingonline.com/2014-layanantradisional-diterapkan-di-70-rs/ diakses 25 Agustus 2017
}

${ }^{10}$ Kementerian Kesehatan Republik Indonesia, 2012, Profil Kesehatan Indonesia Tahun 2012, Jakarta: Kementerian Kesehatan Republik Indonesia. 
dikarenakan belum adanya peraturan perundang-undangan yang secara khusus mengatur mengenai pengobatan tradisional yang dapat diterapkan pada sarana kesehatan seperti rumah sakit dan puskesmas.

Penyehat tradisional maupun pengobat tradisional sesungguhnya memiliki pengetahuan yang amat berharga, bahkan tak kalah ilmiah dibanding ilmu medik barat. Sayangnya, penghargaan atas manikam tersebut belum berwujud pohon keilmuan, yang bisa dipertanggungjawabkan dan mampu menunjukkan bukti signifikan secara ilmiah.

Lemahnya riset dan kemampuan melakukan kajian pustaka, membuat banyak orang dengan mudahnya mencaplok informasi-informasi yang bersliweran di dunia maya yang di negara asalnya justru menjadi bahan tertawaan. Hanya dibutuhkan ketekunan, keuletan, setia pada keilmuan, seorang cendekia mampu membuat dasar keilmuannya berdiri tegak, diakui secara terhormat dengan logika berpikir. Sebaliknya, keserakahan atas kekuasaan dan lahan mata pencaharian, akhirnya mencoreng nilai etika dan keluhuran ilmu pengetahuan.

Peraturan Pemerintah 2014 tentang Pelayanan Kesehatan Tradisional menyebutkan bahwa pelayanan kesehatan tradisional meliputi pelayanan kesehatan tradisional keterampilan dan pelayanan kesehatan tradisional ramuan. Dari kedua jenis pelayanan kesehatan tradisional ini, pemerintah memiliki kewenangan untuk mengatur secara penuh dalam bidang sumber daya manusia kesehatan dan bidang sediaanfFarmasi, alat kesehatan, dan makanan minuman. Pemerintah Daerah Kabupaten/Kota memiliki wewenang luas dan nyata dalam mengatur pelayanan kesehatan tradisional. Pemerintah Daerah Kabupaten/Kota yang dalam hal ini memiliki kewenangan untuk mengatur langsung pelayanan kesehatan tradisional adalah Dinas Kesehatan dan Badan Pengawas Obat dan Makanan. Dinas Kesehatan berkewenangan mengatur Sumber Daya Manusia Tenaga Kesehatan Tradisional dalam hal penerbitan izin praktik dan izin kerja untuk para tenaga kesehatan tradisional yang berkompeten. Sedangkan BPOM bertugas mengatur, meregistrasi dan mengawasi peredaran obat tradisional yang marak beredar dalam masyarakat.

Tujuan dibentuknya Undang-Undang Nomor 36 Tahun 2009 tentang Kesehatan adalah untuk mewujudkan kesejahteraan umum yang dalam hal ini adalah kesehatan masayrakat. Dalam rangka meningkatkan derajat kesehatan masyarakat yang setinggitingginya maka dilakukan berbagi upaya kesehatan yang dapat meningkatkan derajat kesehatan itu sendiri. Dalam Undang-Undang Nomor 36 Tahun 2009 tentang Kesehatan diatur 17 bentuk upaya kesehatan yang diharapkan dapat meningkatkan derajat kesehatan yang setinggi-tingginya. Cita-cita itu didukung pula oleh metode pendekatan pelayanan kesehatan yang bertujuan untuk mengubah paradigma masyarakat mengenai kesehatan. Pada awalnya, pelayanan kesehatan hanya mengejar sifat kuratif pengobatan yaitu mengobati atau menyembuhkan yang sakit. Maka dari itu untuk menciptakan pelayanan kesehatan tradisional yang ideal diperlukan empat metode kesehatan yang saling berkaitan satu sama lain yaitu pendekatan promotif, pendekatan preventif dan pendekatan kuratif dan pendekatan rehabilitatif.

Pendekatan promotif merupakan salah satu pendekatan kesehatan yang bersifat promosi dimana ketika dilakukan suatu pelayanan kesehatan tradisional, pasien yang merasa lebih sehat ketika menggunakan pelayanan kesehatan tradisional dapat 
mempromosikan manfaat pelayanan kesehatan tradisional itu kepada anggota masyarakat yang lain sehingga pengguna pelayanan kesehatan tradisional dapat meningkat. Pendekatan preventif mengatur ke arah pencegahan suatu penyakit. Pelayanan kesehatan tradisional ditujukan untuk mencegah sebelum terjadinya suatu penyakit. Pelayanan kesehatan tradisional empiris diselenggarakan dengan menggunakan kedua metode ini pendekatan promotif dan pendekatan preventif.

Pelayanan kesehatan tradisional empris diselenggarakan dengan menggunakan semua pendekatan pelayanan kesehatan. Untuk menciptakan perlindungan hukum yang ideal terhadap pelayanan kesehatan tradisional maka diperlukan kerjasama dari setiap stakeholders yang terkait dengan pelayanan kesehatan tradisional.

Minat penggunaan pengobatan tradisional, tidak lepas pula dari meningkatnya kompleksitas penyakit yang diderita masyarakat, tentu dibarengi dengan kebutuhan biaya pengobatan yang makin besar. Akibatnya, pengobatan tradisional kembali dilirik sebagai salah satu alternatif pemecahan masalah tersebut. Ditunjang dengan bahan baku alam yang tersedia, serta adanya pengetahuan turun-temurun dari sistem pengobatan tradisional, maka minat masyarakat akan pemanfaatan pengobatan tradisional tetap ada dan semakin meningkat.

Di satu sisi, minat masyarakat terus tumbuh, di sisi lain, fasilitas kesehatan juga terus berupaya mengembangkan kemampuan dalam pelayanan kesehatan tradisional yang aman dan berkualitas. Meningkatnya pemanfaatan layanan kesehatan tradisional tentu saja perlu dibarengi dengan kajian penguatan hukum terhadapnya. Perannya sebagai salah satu tenaga kesehatan masyarakat perlu didorong perannya. Selain isu keamanan dan keselamatan konsumen, seorang pengobat tradisional perlu mendapatkan perlindungan hukum terhadap profesinya.

\section{Peran Pemerintah Daerah Kabupaten Semarang dalam Melaksanakan Wewenangnya Menerapkan Aspek Perlindungan Hukum Bagi Penyehat Pengobatan Tradisional Empiris}

Petugas kesehatan yang melakukan pelayanan kesehatan tradisional memiliki syaratsyarat dan kompetensi yang berbeda dalam melakukan pelayanan kepada publik. Untuk pelayanan kesehatan empiris, tenaga kesehatannya disebut penyehat tradisional. Syarat untuk menjadi seorang penyehat tradisional harus memiliki keterampilan dan memiliki Surat Terdaftar Penyehat Tradisional (STPT) yang dikeluarkan oleh Dinas Kesehatan setempat. Untuk pelayanan kesehatan komplementer, tenaga kesehatannya disebut tenaga kesehatan tradisional. Syarat untuk menjadi seorang tenaga kesehatan tradisional prosesnya tidak semudah penyehat tradisional. Para tenaga kesehatan tradisional harus memiliki keterampilan dari sekolah tinggi tertentu, setara minimal pendidikan D3 dan juga harus memiliki Surat Tanda Registrasi Tenaga Kesehatan Tradisional (STRTKT) dan Surat Izin Praktek Tenaga Kesehatan Tradisional (SIPTKT) yang dikeluarkan oleh pemerintah daerah. Pemerintah memiliki kewenangan penuh dalam mengatur dan menegakkan peraturan dalam mengawasi peredaran obat tradisional. Pemerintah perlu bertindak tegas dalam mengatur peredaran obat tradisional yang beredar dalam masyarakat. Banyak beredar obat tradisional yang tidak terdaftar bahkan mengandung bahan kimia yang dapat membahayakan masyarakat. Belum lagi pelayanan kesehatan tradisional melalui 
pendekatan agama dan pendekatan supranatural yang dirasakan belum ada pengaturan yang jelas dari pemerintah.

Sebelumnya dikatakan, bahwa pelayanan kesehatan tradisional merupakan teknik pengobatan dengan cara,serta obatan yang mengacu pada pengalaman dan keterampilan secara turun temurun secara empiris, dapat dipertanggung jawabkan dan diterapkan sesuai dengan norma yang berlaku di masyarakat, pengalaman dan keterampilan turun temurun yang dapat dipertanggungjawabkan dan diterapkan merupakan unsur yang penting dalam menyelenggarakan suatu pelayanan kesehatan tradisional. Pengalaman dan keterampilan pelayanan kesehatan tradisional harus dapat dibuktikan sebagai sesuatu yang berdaya guna bagi masyarakat, aman untuk dilakukan dan tentunya dapat meningkatkan derajat kesehatan setinggi-setingginya. Dalam masyarakat, pelayanan kesehatan tradisional ini semakin berkembang dan beragam bentuk dalam masyarakat. Pemerintah perlu mengatur secara tegas mengenai pelayanan kesehatan tradisional ini agar tidak keluar dari jalur tujuan kesehatan itu sendiri yaitu meningkatkan derajat kesehatan yang setinggi-tinginya. Perlu adanya perlindungan hukum terhadap pelayanan kesehatan tradisional yang bertujuan untuk melindungi para tenaga kesehatan tradisional maupun pengguna pelayanan kesehatan tradisional itu sendiri.

Negara sebagai pemegang kekuasaan tertinggi seharusnya dapat menjamin penyelenggaraan kesehatan dalam bentuk pelayanan kesehatan tradisional agar dapat berjalan sebagaimana mestinya karena hakekat pemerintahan sendiri adalah pelayan pada masyarakat. Pemerintahan ada dikarenakan kehendak rakyat, untuk itu pemerintahan diadakan bukan untuk melayani dirinya sendiri, tetapi untuk melayani masyarakat juga menciptakan kondisi yang menginginkan setiap masyarakat mengembangkan kemampuan dan kreativitasnya demi mencapai tujuan bersama. ${ }^{11}$ Penentuan pengaturan bidang-bidang tersebut didasari oleh kewenangan atau wewenang pemerintah baik itu pemerintah pusat maupun daerah. Kewenangan menjadi kunci penentuan terlaksananya urusan pemerintahan tersebut.

UU RI No 23 th 2014 tentang Pemerintahan Daerah menyebutkan bahwa kewenangan pemerintah dapat direfleksikan melalui pembagian urusan pemerintahan yang dibagi menjadi tiga kategori, yaitu: urusan pemerintahan absolut, urusan pemerintahan konkuren, dan urusan pemerintahan umum. Kategorisasi urusan pemerintahan ini muncul untuk menunjukkan prioritas pengaturan dan pengurusan yang dilakukan oleh pemerintah pusat, dan pemerintah daerah. Urusan pemerintahan absolut berada pada wewenang Pemerintah Pusat dan dapat dilimpahkan kepada pemerintahan daerah dengan berdasarkan asas dekonsentrasi. Urusan pada Pemerintahan Konkuren menjadi kewenangan Daerah,yang terdiri atas Urusan Pemerintahan Wajib dan Urusan Pemerintahan Pilihan. Urusan Pemerintahan Umum ini merupakan urusan pemerintahan yang menjadi kewenangan presiden sebagai kepala pemerintahan.

Salah satu kaitan kewenangan dengan pengkategorian urusan pemerintahan mengenai kesehatan terdapat dalam bagian urusan pemerintahan konkuren yang mengatur mengenai Urusan Pemerintahan Wajib yang berkaitan dengan berbagai Pelayanan Dasar dan Urusan Pemerintahan yang tidak berkaitan dengan Pelayanan

11 Ryas Rasyid, t.th., Desentralisasi Dalam Menunjang Pembangunan Daerah Dalam Pembangunan Administrasi Di Indonesia, Jakarta: LP3ES, hlm. 13 
Dasar. Pasal 12 (1) UU No 23 Tahun 2014 tentang Pemerintahan Daerah membagi Urusan Pemerintahan Wajib yang berkaitan dengan Pelayanan Dasar meliputi:

1. pendidikan;dan

2. kesehatan masyarakat

3. pekerjaan umum serta penataan ruang;

4. perumahan rakyat dan disertai kawasan permukiman;

5. ketenteraman, ketertiban umum, dan pelindungan masyarakat; dan

6. sosial.

Pemerintah sebagai pemegang kekuasaan tertinggi dan pemilik kewenangan untuk mengatur bidang kesehatan memiliki tanggung jawab untuk memenuhi hak atas kesehatan yang merupakan salah satu hak asasi manusia dan merupakan salah satu unsur kesejahteraan yang harus diwujudkan untuk mencapai cita-cita bangsa Indonesia. Indonesia sebagai negara yang menganut konsep negara kesejahteraan, sebagaimana diungkapkan Jimly Asshiddiqie yang dikutip oleh W. Riawan Tjandra dituntut untuk memperluas tanggung jawabnya kepada masalah-masalah yang dihadapi oleh rakyat banyak. Fungsi negara pun diperluas meliputi pelayanan sosial kepada individu dan keluarga dalam hal-hal khusus, seperti 'social security', kesehatan, kesejahteraan sosial, pendidikan dan pelatihan serta perumahan. ${ }^{12}$

Tingkat kesehatan masyarakat, akan sangat berpengaruh pada tingkat kesejahteraan masyarakat yang memiliki keterkaitan yang erat dengan kemiskinan. Tingkat kemiskinan pun akan terkait dengan tingkat kesejahteraan. Kesehatan merupakan faktor utama dalam upaya peningkatan kesejahteraan masyarakat, maka kesehatan akan selalu menjadi perhatian utama pada pemerintah sebagai penyelenggara pelayanan publik. Pemerintah seharusnya dapat menjamin hak masyarakat untuk menjadi sehat dengan memberikan pelayanan kesehatan secara adil, merata, memadai, terjangkau, dan berkualitas. ${ }^{13}$ Karena tanpa memenuhi hak atas kesehatan, maka welfare state tidak akan terwujud. ${ }^{14}$

Sebagai pengemban amanat untuk menyejahterakan masyarakat maka negara berkewajiban untuk menghormati, melindungi dan memenuhi hak-hak asasi kesehatan tersebut. Kewajiban menghormati itu seperti menciptakan persamaan akses pelayanan kesehatan, pencegahan dari tindakan-tindakan yang dapat menurunkan status kesehatan masyarakat, melakukan langkah-langkah legislasi yang dapat menjamin perlindungan kesehatan masyarakat, membuat kebijakan kesehatan, penyediaan anggaran yang memadai, penyediaan jasa-jasa pelayanan kesehatan tradisional yang yang layak dan memadai untuk seluruh masyarakat.

Setiap penyelenggaraan kenegaraan dan pemerintahan memiliki legitimasi, didalam kewenangan yang diberikan oleh undang-undang. Sehingga secara normatif menjadi

\footnotetext{
12 W. Riawan Tjandra, 2008, Hukum Administrasi Negara, Yogyakarta: Universitas Atma Jaya, hlm. 9

${ }^{13}$ Radhitya Widyasworo, 2014, Analisis Pengaruh Pendidikan, Kesehatan, Dan Angkatan Kerja Wanita Terhadap Kemiskinan Di Kabupaten Gresik (Studi Kasus Tahun 2008 2012), Jurnal Ilmiah, Malang: Fakultas Ekonomi Dan Bisnis Universitas Brawijaya, hlm. 4

14 Mailinda Eka Yuniza, 2013, Pengaturan Pelayanan Kesehatan Di Kota Yogyakarta Setelah Penerapan Otonomi Luas, Mimbar Hukum Volume 25, Nomor 3, Oktober 2013, hIm. 378
} 
penyebab setiap tindakan pemerintah,yang harus berdasarkan peraturan perundangundangan, atau yang berdasarkan pada kewenangan. Wewenang pemerintahan ini sekaligus menjadi fungsi kontrol rakyat terhadap pemerintah dalam bertindak. Wewenang pemerintah bersifat atribusi yang berasal dari peraturan perundangundangan. Dengan kata lain, organ pemerintah memperoleh kewenangan secara langsung dari redaksi pasal tertentu dalam suatu peraturan perundang-undangan. Setiap pemberian kewenangan kepada pejabat pemerintahan tertentu, tersirat di dalamnya pertanggungjawaban dari pejabat yang bersangkutan.

Ada beberapa cara perlindungan secara hukum, antara lain sebagai berikut:

1. Membuat peraturan (by giving regulation), yang bertujuan untuk:

a. Memberikan hak dan kewajiban;

b. Menjamin hak-hak para subyek hukum

2. Menegakkan peraturan (by the law enforcement) melalui:

a. Hukum Administrasi Negara, berfungsi juga sebagai mencegah (preventif) terjadinya pelanggaran pada hak-hak konsumen, dengan perijinan dan pengawasan.

b. Hukum pidana yang berfungsi untuk menanggulangi (repressive) setiap pelanggaran terhadap peraturan perundang-undangan, dengan cara mengenakan sanksi hukum berupa sanksi pidana dan hukuman;

c. Hukum perdata yang berfungsi untuk memulihkan hak (curative, recovery), dengan membayar kompensasi atau ganti kerugian. ${ }^{15}$

Perlindungan hukum terhadap pelayanan kesehatan tradisional haruslah dapat mencakup kepentingan semua stakeholders yaitu tenaga kesehatan tradisional maupun pasien pelayanan kesehatan tradisional. Kewenangan pemerintah dalam melindungi stakeholders pelayanan kesehatan tradisional dapat ditinjau dari segi hukum kesehatan, hukum pemerintahan daerah, hukum perlindungan konsumen, dan juga hukum pidana. Dalam melindungi para stakeholders pelayanan kesehatan tradisional pemerintah berwenang dan berkewajiban untuk membuat dan menegakkan peraturan mengenai pelayanan kesehatan tradisional secara menyeluruh sehingga dapat melindungi seluruh stakeholders.

Pemerintah mengatur mengenai pelayanan kesehatan tradisional dalam UU Kesehatan 2009 dan PP th 2014 tentang Pelayanan Kesehatan Tradisional. Peraturan tentang Pelayanan Kesehatan Tradisional mengatur pelayanan kesehatan tradisional lebih rinci dan menyeluruh apabila dibandingkan dengan UU Kesehatan th 2009, yang hanya mengatur dalam beberapa pasal yaitu Pasal 1 Angka 9, Pasal 1 Angka 16, Pasal 48, Pasal 48, Pasal 59, Pasal 60 dan Pasal 61.

Berdasarkan hasil wawancara penulis dengan Agus Purwanto, ${ }^{16}$ selaku Pembina Penyehat Tradisional Dinas Kesehatan Kabupaten Semarang, diperoleh keterangan bahwa Peraturan Pemerintah 2014 diundangkan untuk memberikan perlindungan

\footnotetext{
15 Wahyu Sasongko, 2007, Ketentuan-Ketentuan Pokok Hukum Perlindungan Konsumen, Bandar Lampung: Penerbit Universitas Lampung, hlm. 31

${ }^{16}$ Wawancara dengan Agus Purwanto, selaku Pembina Penyehat Tradisional Dinas Kesehatan Kabupaten Semarang, pada tanggal 12 April 2017
} 
hukum bagi penyehat tradisional supaya tidak terjadi persinggungan dengan UU Kesehatan th 2009 dan UU th 2004 tentang Praktek Kedokteran.

Menurut Agus Purwanto, ${ }^{17}$ selaku Pembina Penyehat Tradisional Dinas Kesehatan Kabupaten Semarang,dengan adannya Peraturan ini dibuat untuk menjabarkan Undang-Undang No 36 Tahun 2009 tentang Kesehatan. Didalam Peraturan Pemerintah tentang Pelayanan Kesehatan Tradisional, pengobatan tradisional dibagi menjadi 3 (tiga) bagian, yaitu: pengobatan tradisional empiris, pengobatan tradisional komplementer dan pengobatan tradisional integrasi.

Berdasarkan hasil wawancara penulis dengan Agus Purwanto, ${ }^{18}$ selaku Pembina Penyehat Tradisional Dinas Kesehatan Kabupaten Semarang, diperoleh keterangan bahwa pada dasarnya Peraturan Pemerintah ini dibuat untuk meningkatkan sumber daya manusia penyehat tradisional. Akan tetapi untuk lebih baik lagi jika diatur dalam Peraturan Menteri Kesehatan.

Menurut Agus Purwanto, ${ }^{19}$ selaku Pembina Penyehat Tradisional Dinas Kesehatan Kabupaten Semarang dengan adanya Peraturan Pemerintah Nomor 103 Tahun 2014 tentang Pelayanan Kesehatan Tradisional nantinya akan banyak yang mengabaikan aturannya dan banyak yang tidak mengajukan keahliannya atau mendaftarkan keahliannya pada Dinas Kesehatan sebagai pembina penyehat tradisional dikarenakan Peraturan ini tidak menutup secara sepihak dan belum adanya peraturan daerah yang mengatur mengenai penyelenggaraan penyehat pengobatan tradisional.

Hasil penelitian menunjukkan bahwa UU Kesehatan 2009 ini mengalami deregulasi karena banyak ditemukan kekosongan hukum yang akhirnya diakomodasi oleh Peraturan Pemerintah 2014.

Hal ini menunjukkan bahwa UU Kesehatan tidak memberikan perlindungan hukum yang penuh terhadap pelayanan kesehatan tradisional karena lebih banyak mengatur hal-hal yang bersifat prinsipil atau mendasar mengacu pada tujuan kegiatan upaya kesehatan yang diharapkan dapat meningkatkan derajat kesehatan setinggi-tingginya. Agar tercipta suatu kesesuaian hukum positif yang berlaku dalam masyarakat yang sesuai dengan hierarki peraturan perundang-undangan nasional perlu dibentuk suatu Undang-undang mengenai pelayanan kesehatan tradisional yang dapat memberikan kepastian hukum bagi setiap stakeholders pelayanan kesehatan masyarakat tradisional.

Didalam Pasal 1, Undang-Undang 1945 menyatakan bahwa Negara Indonesia adalah negara kesatuan yang berbentuk Republik. Karena itu menimbulkan konsekuensi logis sebagai Negara kesatuan adalah dibentuknya pemerintah Negara Indonesia sebagai pemerintah nasional yang memiliki tugas untuk membentuk suatu daerah sebagai bagian dari negara kesatuan Indonesia. Kemudian, Pasal 18 ayat (2), ayat (5) UU Dasar 1945 menyatakan bahwa Pemerintahan Daerah berwenang mengatur dan mengurus

\footnotetext{
17 Wawancara dengan Agus Purwanto, selaku Pembina Penyehat Tradisional Dinas Kesehatan Kabupaten Semarang, pada tanggal 12 April 2017

18 Wawancara dengan Agus Purwanto, selaku Pembina Penyehat Tradisional Dinas Kesehatan Kabupaten Semarang, pada tanggal 12 April 2017

19 Wawancara dengan Agus Purwanto, selaku Pembina Penyehat Tradisional Dinas Kesehatan Kabupaten Semarang, pada tanggal 12 April 2017
} 
sendiri Urusan Pemerintahan menurut Asas Otonomi, Tugas Pembantuan dan diberikan otonomi yang seluas-luasnya.

Dalam UU no 23 Tahun 2014 tentang Pemerintahan Daerah, menyebutkan bahwa Urusan Pemerintahan adalah Urusan Pemerintahan adalah kekuasaan Pemerintahan yang menjadi kewenangan Presiden yang pelaksanaannya dilakukan oleh Kementerian Negara, dan penyelenggara Pemerintahan Daerah untuk melindungi, melayani, memberdayakan, serta mensejahterakan masyarakat. Dalam hal ini, pemerintah daerah memiliki kewenangan untuk mengatur pelayanan kesehatan tradisional sehingga fungsi pelayanan kesehatan tradisional dapat melindungi, melayani, memberdayakan dan menyejahterakan masyarakat.

Fungsi melindungi lebih dilakukan kearah membuat suatu undang-undang khusus yang mengatur mengenai pelayanan kesehatan tradisional. Undang-Undang Nomor 36 Tahun 2009 tentang Kesehatan tidak mengakomodasi secara penuh kepentingan stakeholders pelayanan kesehatan tradisional. Oleh karena itu, pemerintah hendaknya membentuk suatu undang-undang khusus yang dapat melakukan pengaturan pelayanan kesehatan tradisional secara menyeluruh. Peraturan Pemerintah Nomor 103 Tahun 2014 tentang Pelayanan Kesehatan Tradisional dapat menjadi suatu peraturan yang memberikan kepastian hukum dan perlindungan hukum bagi setiap stakeholders pelayanan kesehatan tradisional. Di dalamnya perlu dicantumkan berbagai peraturan yang tersebar dalam Peraturan Pemerintah tentang Pelayanan Kesehatan Tradisional dan berbagai keputusan menteri mengenai pelayanan kesehatan tradisional dan peredaran obat tradisional mengingat pelayanan kesehatan tradisional tidak dapat dipisahkan dengan penggunaan obat tradisional. Dengan adanya pembentukan Peraturan Pemerintah tentang Pelayanan Kesehatan Tradisional yang mengatur dengan lengkap mengenai pelayanan kesehatan tradisional tentunya akan serta merta melindungi pelayanan kesehatan tradisional itu sendiri karena pengaturan oleh undang-undang yang khusus akan memberikan kekuatan yang bersifat mengikat.

Dalam fungsi melayani, Pemerintah berwenang menetapkan standar-standar pelayanan kesehatan tradisional. Dimulai dari standar pendidikan dan kompetensi yang seharusnya dimiliki oleh penyehat tradisional maupun tenaga kesehatan tradisional. Selain itu standar lain yang perlu ditentukan oleh pemerintah adalah standar tempat pelayanan seperti bangunan dan ruangan yang memadai seperti yang diatur oleh Peraturan Pemerintah Nomor 103 Tahun 2014 tentang Pelayanan Kesehatan Tradisional. Fungsi melayani dapat juga diterapkan dalam proses pemberian izin oleh pemerintah kepada penyehat tradisional maupun tenaga kesehatan tradisional, pemerintah perlu membuat suatu sistem perizinan yang lebih efektif dan efisien sehingga dapat mengembangkan pelayanan kesehatan tradisional menjadi suatu bentuk usaha kesehatan.

Fungsi memberdayakan lebih ditujukan kepada fungsi pemerintah untuk mengembangkan pelayanan kesehatan itu sendiri. Pemerintah harus dapat mengatur bahkan mengakomodasi agar terjadi peningkatan kederajatan suatu pelayanan kesehatan tradisional. Misalnya dalam pelayanan kesehatan empiris, pemerintah perlu mempertimbangkan untuk membuat sekolah atau tempat pendidikan untuk meningkatkan derajat pelayanan kesehatan empiris. Memberdayakan juga mengarahkan masyarakat untuk lebih mempercayai dan menggunakan pelayanan kesehatan tradisional, semakin banyak masyarakat yang menggunakan pelayanan 
kesehatan tradisional akan menyebabkan derajat kesehatan masyarakat semakin meningkat.

Fungsi yang terakhir adalah fungsi menyejahterakan, fungsi ini berisi kewenangan pemerintah untuk mengatur kesejahteraan pelayanan kesehatan tradisional maupun pasien atau klien pelayanan kesehatan tradisional. Pemerintah memiliki kewenangan untuk mengatur ukuran imbalan jasa bagi pelayanan kesehatan tradisional agar tidak terlalu murah bahkan tidak terlalu mahal seperti kebanyakan pelayanan kesehatan konvensional. Pemerintah memiliki kewenangan untuk mengatur agar pelayanan kesehatan tradisional dapat menjadi suatu pelayanan kesehatan yang bermutu bagi masyarakat dan dapat membantu masyarakat mendapatkan pelayanan kesehatan yang terbaik. Masyarakat yang sehat akan memberikan sumber daya manusia yang sehat dan berkualitas bagi pembangunan nasional.

\section{Penyehat Tradisional Menerapkan Ketentuan Perundang-undangan Terkait Dengan Praktek Pengobatan Tradisionalnya di Kabupaten Semarang.}

Didalam pembukaan UUD 1945 tercantum jelas cita-cita Bangsa Indonesia yang sekaligus merupakan tujuan Nasional Bangsa Indonesia. Tujuan Nasional tersebut adalah melindungi seluruh Bangsa Indonesia dan seluruh tumpah darah Indonesia, untuk memajukan kesejahteraan umum,serta mencerdaskan kehidupan Bangsa dan ikut melaksanakan ketertiban dunia yang berdasarkan kemerdekaan, perdamaian abadi, serta keadilan sosial. Untuk mencapai tujuan nasional diselenggarakanlah upaya pembangunan, yang berkesinambungan serta merupakan suatu rangkaian pembanguna menyeluruh, terarah dan terpadu, termasuk juga di antaranya pembangunan kesehatan.

Kesehatan adalah merupakan hak asasi manusia, salah satu dari unsur kesejahteraan yang harus diwujudkan oleh negara sesuai dengan cita-cita bangsa Indonesia sebagaimana dimaksud didalam Pancasila dan Pembukaan Undang-Undang Dasar Negara Republik Indonesia Tahun 1945.Maka disetiap kegiatan, upaya untuk meningkatkan derajat kesehatan masyarakat yang setinggi-tingginya, dilaksanakan berdasarkan prinsip nondiskriminatif, partisipatif, perlindungan,yang berkelanjutan dan sangat penting artinya bagi pembentukan sumber daya manusia Indonesia, peningkatan ketahanan dan daya saing bangsa, serta pembangunan nasional.

Pembangunan nasional harus dilandasi dengan wawasan kesehatan yang artinya pembangunan nasional itu sendiri harus memperhatikan kesehatan masyarakat. Apabila terjadi suatu hal yang menyebabkan gangguan kesehatan pada masyarakat Indonesia tentunya akan menimbulkan kerugian ekonomi yang besar bagi negara, tapi di sisi lain setiap keberhasilan upaya peningkatan derajat kesehatan masyarakat akan meningkatkan investasi bagi pembangunan negara. Oleh karena itu, semua pihak baik pemerintah maupun masyarakat bertanggung jawab dalam memperhatikan kesehatan masyarakat.

Sebagai pemegang kekuasaan tertinggi, Negara bertanggung jawab dalam mengatur setiap upaya peningkatan derajat kesehatan masyarakat. Atas dasar itulah maka Negara membentuk Undang- Undang Kesehatan untuk mengatur mengenai bidang kesehatan di Indonesia. 
Arti Kesehatan memiliki makna dan dimensi yang luas sesuai definisi menurut WHO maupun UU Kesehatan, yaitu keadaan sehat yang meliputi aspek fisik, mental, spiritual dan sosial serta dapat produktif secara sosial maupun ekonomis. Hal ini menunjukkan bahwa status kesehatan seseorang tidak hanya diukur dari aspek fisik dan mental semata, namun juga dinilai berdasarkan produktivitas sosial atau ekonomi. Kesehatan mental (jiwa) mencakup komponen pikiran, emosional dan spiritual. Secara spiritual, sehat tercermin dari praktek keagamaan, kepercayaan, dan perbuatan yang baik sesuai norma dalam masyarakat. ${ }^{20}$ Dalam upaya peningkatan derajat kesehatan masyarakat diperlukan suatu peningkatan kesehatan.

"Pencapaian kesehatan merupakan kegiatan dan/atau serangkaian kegiatan yang dilakukan secara terpadu, terintegrasi dan berkesinambungan, memelihara,disertai meningkatkan derajat kesehatan masyarakat dalam bentuk pencegahan suatu penyakit, peningkatan kesehatan, pengobatan penyakit, seerta pemulihan kesehatan oleh pemerintah dan/atau masyarakat".

Dalam mewujudkan derajat kesehatan yang setinggi-tingginya bagi masyarakat diselenggarakan upaya kesehatan yang terpadu dan menyeluruh dalam bentuk upaya kesehatan perorangan dan upaya kesehatan masyarakat. Upaya kesehatan diselenggarakan dalam bentuk kegiatan dengan pendekatan promotif, preventif, kuratif, dan rehabilitatif yang dilaksanakan secara terpadu, menyeluruh.

Penyelenggaraan upaya kesehatan dilaksanakan melalui kegiatan:

1. pelayanan kesehatan;

2. pelayanan kesehatan tradisional;

3. peningkatan kesehatan dan pencegahan penyakit;

4. penyembuhan penyakit dan pemulihan kesehatan;

5. kesehatan reproduksi;

6. keluarga berencana;

7. kesehatan sekolah;

8. kesehatan olahraga;

9. pelayanan kesehatan pada bencana;

10. pelayanan darah;

11. kesehatan gigi dan mulut;

12. penanggulangan gangguan penglihatan dan gangguan pendengaran;

13. kesehatan matra;

14. pengamanan dan penggunaan sediaan farmasi dan alat kesehatan;

15. pengamanan makanan dan minuman;

16. pengamanan zat adiktif; dan/atau

17. bedah mayat.

Di dalam masyarakat Indonesia, dikenal 2 (dua) teknik pengobatan yaitu pengobatan konvensional dan pengobatan tradisional. Pengobatan konvensional merupakan suatu teknik pengobatan modern yang dilakukan oleh seorang dokter. Sedangkan pengobatan tradisional merupakan pengobatan/atau perawatan dengan cara, obat maupun pengobatannya mengacu kepada pengalaman, keterampilan turun temurun, dan pendidikan/pelatihan, dan diterapkan sesuai dengan norma yang berlaku dalam

${ }^{20}$ Soekidjo Notoatmodjo, 2003, Pendidikan dan Perilaku Kesehatan, Jakarta: PT. Rineka Cipta, hIm. 3-4 
masyarakat. Teknik-teknik pengobatan itu dapat dikelompokan menjadi dua jenis pelayanan kesehatan yaitu:

1. Pelayanan kesehatan konvensional atau pelayanan kesehatan modern adalah pengobatan yang dilakukan oleh seorang dokter .Dengan metode Ilmiah dan teruji dengan sebuah penelitian dan dapat dipertanggungjawabkan.

2. Pelayanan kesehatan tradisional merupakan pengobatan atau perawatan dengan cara dan obat ramuan,keahlian dalam keterampilan turun temurun secara empiris yang dapat dipertanggung-jawabkan dan diterapkan sesuai dengan norma yang berlaku di masyarakat.

Pelayanan kesehatan tradisional sudah dikenal terlebih dahulu daripada pelayanan kesehatan konvensional. Keberadaan pelayanan kesehatan konvensional muncul setelah pelayanan kesehatan tradisional pada abad ke-19. Hanya saja karena metode yang digunakan lebih ilmiah dan teruji membuat pelayanan kesehatan konvensional lebih dipercaya oleh masyarakat. Tetapi ternyata dalam perkembangannya, pelayanan kesehatan tradisional yang umumnya banyak terdapat di masyarakat pedesaan mulai menarik kembali kepercayaan masyarakat perkotaan terhadap pelayanan kesehatan tradisional. Malpraktik pelayanan kesehatan konvensional membuat masyarakat membuka diri kembali pada pelayanan kesehatan tradisional yang menawarkan konsep back to the nature bahkan kemungkinan sembuh dari penyakit yang belum ditemukan obatnya di dunia medis.

Peraturan Pemerintah tahun 2014 tentang Pelayanan Kesehatan Tradisional,membagi dalam bidang Pelayanan Kesehatan Tradisional menjadi:

1. Pelayanan Kesehatan Tradisional Empiris

adalah penerapan kesehatan tradisional yang manfaat dan keamanannya terbukti secara empiris.

2. Pelayanan Kesehatan Tradisional Komplementer adalah penerapan kesehatan tradisional yang memanfaatkan ilmu biomedis dan biokultural dalam penjelasannya serta manfaat dan keamanannya terbukti secara ilmiah.

3. Pelayanan Kesehatan Tradisional Integrasi

adalah suatu bentuk pelayanan kesehatan yang meng-kombinasikan pelayanan kesehatan konvensional dengan Pelayanan Kesehatan Tradisional Komplementer, baik bersifat sebagai pelengkap atau pengganti.

Berdasarkan cara pengobatannya terbagi menjadi:

1. Pelayanan yang menggunakan keterampilan; dan

2. Pelayanan yang menggunakan ramuan.

Pengobatan Tradisional adalah salah satu upaya pengobatan dan/atau perawatan diluar ilmu kedokteran dan/atau ilmu keperawatan yang dilakukan sebagai upaya peningkatan kesehatan, pecegahan penyakit, penyembuhan penyakit, dan/atau pemulihan kesehatan.

Penyehat tradisiona I dijalankan atau dilakukan oleh pengobat tradisional (battra) yang telah memiliki Surat Terdaftar Pengobat Tradisional (STPT), yaitu bukti tertulis yang diberikan kepada pengobat tradisional yang telah melaksanakan pendaftaran, atau yang telah memiliki Surat Izin Pengobat Tradisional (SIPT), yaitu diberikan 
kepada pengobat tradisional yang metodenya telah dikaji, diteliti dan diuji terbukti aman dan bermanfaat bagi kesehatan.

Pelayanan Kesehatan Tradisional dalam menjalankan kegiatannya dengan tujuan untuk mengobati atau menyembuhkan orang sakit, tidak menutup kemungkinan untuk mencari manfaat ekonomis pula. Jadi secara umum penyedia jasa pelayanan kesehatan tradisional dapat dikatakan sebagai pelaku usaha yang bergerak dalam bidang pelayanan jasa kesehatan, yaitu pelayanan kesehatan tradisional. Hal ini sesuai dengan definisi pelaku usaha dalam Pasal 1 angka 3 UU Perlindungan Konsumen no 8 th 1999 yang bermakna luas. Pengertian tersebut pelaku usaha akan memudahkan konsumen dalam hal untuk menuntut ganti kerugian bila terdapat permasalahan hukum.

Jika dilihat dari ada atau tidaknya kerugian yang diderita dalam hubungan antara konsumen dengan pelaku usaha dari penggunaan, pemanfaatan oleh konsumen atas barang dan/atau jasa, yang dihasilkan oleh pelaku usaha, maka tidak akan terlepas dari adanya pertanggungjawaban hukum.

Berbicara tentang tanggung jawab, maka terlebih dahulu harus membicarakan mengenai kewajiban. Dari kewajiban (duty, obligation) akan lahir tanggung jawab. Tanggung jawab timbul karena seseorang atau suatu pihak mempunyai suatu kewajiban, termasuk kewajiban karena undang-undang dan hukum (statutory obligation).

Pelaku pengobat tradisional hanya dapat menggunakan peralatan yang aman bagi kesehatan dan sesuai dengan metode/keilmuannya, dan adanya larangan menggunakan peralatan kedokteran serta penunjang diagnostik kedokteran.

Pertanggung jawaban sebagai pelaku usaha yaitu, kewajiban yang dilakukan oleh pelaku usaha, ketika adanya konsumen menderita kerugian setelah pemakaian/ mengkonsumsi produk barang atau jasa yang ditawarkan. Tanggung jawab ini dapat terkait dan diminta tanggung jawabnya,seberapa besar serta bagaimana cara mengganti kerugian tersebut.

Dalam pengertian pengobatan tradisional yang diatur pada UU kesehatan dan peraturan pemerintah tentang pelayanan kesehatan tradisional, belum adanya UU yang mengatur secara khusus mengenai kewajiban, hak selaku pelaku usaha pengobatan tradisional serta konsumen pengobatan tradisional. Dapat diketahui bahwanya pengobatan tradisional juga disebut sebagai pengobatan nonkonvensional ini, merupakan cara perawatan/penyembuhan ataupun dari alat yang dipakai, serta tenaga kesehatannya pun berbeda. Dimana Pelayanan kesehatan diluar medis menjadi salah satu pilihan yang dijadikan alternatif bagi konsumen jasa. Dengan alasan karena biaya yang trejangkau.

Berdasarkan hasil wawancara penulis dengan Muhamad Ali Zabidi (Ki Suro Setriko) ${ }^{21}$ sebagai seorang pengobat tradisional yang mempunyak keahlian prana dan terapis menggunakan setrika, diperoleh keterangan bahwa dalam menanggapi adanya Peraturan Pemerintah No 103 Tahun 2014 tentang Pelayanan Kesehatan Tradisional, beliau setuju untuk dilakukan aturan-aturan yang mengatur penyehat tradisional.

${ }^{21}$ Wawancara dengan Mihamad Ali Zabidi (Ki Suro Setriko), pada tanggal 22 Agustus 2017 
Namun dengan adanya peraturan ini banyak nantinya yang tidak bisa mendapatkan ijin karena keahlian pengobat tradisional tidak ada di dalam aturan Peraturan Pemerintah 2014 tentang Pelayanan Kesehatann Tradisional ini. Beliau menyarankan bahwa perlu adanya aturan yang lebih mendalam untuk pengobat tradisional yang mempunyai banyak keahlian dari turun temurun.

Berdasarkan hasil wawancara penulis dengan Jatmiko, ${ }^{22}$ seorang terapis di Kabupaten Semarang, beliau terjun sebagai terapis karena ingin menolong sesama. Beliau mempunyai keahlian terapis tersebut dari gurunya/belajar secara turun temurun. Beliau sudah praktek selama 12 tahun dan sudan mempunyai ijin di Dinas Kesehatan Kabupaten Semarang. Beliau mempunyai keahlian pijat, refleksi, akupresur, bekam, herbal dan sedikit spiritual.

Menurut Jatmiko, ${ }^{23}$ seorang terapis di Kabupaten Semarang, dengan adanya peraturan ini secara keilmuan penyehat tradisional benar-benar ditata, ke pihak pasien juga lebih aman, apalagi sekarang menuju ke profesi/keahlian. Perlindungan hukum itu tidak diperlukan apabila semua sudah mengikiti aturan yang berlaku.

Berdasarkan hasil wawancara penulis dengan Jatmiko, ${ }^{24}$ seorang terapis di Kabupaten Semarang, beliau setuju dengan dengan adanya Peraturan ini, akan tetapi ada belum pas dalam peraturan tersebut, yaitu penyehat tradisional mempunyai banyak ketrampilan akan tetapi tidak bisa diterapkan semua karena terbentur pada aturan ini.

Menurut Jatmiko, ${ }^{25}$ seorang terapis di Kabupaten Semarang, Peraturan Pemerintah tentang Pelayanan Kesehatan Tradisional tersebut hanya memberikan ijin pada satu keahlian saja pada penyehat pengobatan tradisional empiris. Inilah yang membuat dilema dan yang mengganjal di hati para penyehat tradisional.

Penyehat dalam menjalankan usahanya dibidang pelayanan pengobatan tradisional dapat dikatakan sebagai pelaku usaha, seperti dijelaskan diatas. Meski telah adanya UU kesehatan dan Peraturan perundang-undangan lainnya tidak ada yang menyatakan bahwa pengobat tradisional merupakan pelaku usaha, dapat dilihat unsur-unsur pelaku usaha yang tertuang pada UU Nomor 8 tahun 1999 Perlindungan Konsumen, Pasal 1 angka 3, yaitu:

1. Setiap orang atau badan usaha

2. Yang didirikan atau berkedudukan

3. Melakukan kegiatan

4. Dalam wilayan hukum Republik Indonesia

5. Sendiri atau bersama-sama

6. Melalui perjanjian

7. Menyelenggarakan kegiatan usaha

8. Bidang ekonomi

22 Wawancara dengan Jatmiko, seorang terapis di Kabupaten Semarang, pada tanggal 21 Juli 2017

${ }^{23}$ Wawancara dengan Jatmiko, seorang terapis di Kabupaten Semarang, pada tanggal 21 Juli 2017

${ }^{24}$ Wawancara dengan Jatmiko, seorang terapis di Kabupaten Semarang, pada tanggal 21 Juli 2017

${ }^{25}$ Wawancara dengan Jatmiko, seorang terapis di Kabupaten Semarang, pada tanggal 21 Juli 2017 
Seorang pelaku usaha merupakan seseorang, badan hukum atau non hokum, yang melakukan kegiatan usahanya , di berbagai bidang ekonomi, baik sendiri maupun secara bersama-sama didalam wilayah Republik Indonesia, mencari keuntungan dari konsumen. Pelaku usaha pengobatan tradisional yang bergerak dibidang pelayanan pengobatan tradisional di Indonesia dengan mencari keuntungan yaitu menjual keahliannya, dalam jasa penyembuhan maupun perawatan dapat disebut sebagai pelaku usaha.Mempunyai kewajiban yang harus dipenuhi oleh konsumen yaitu membayar sejumlah uang sebesar yang telah disepakati. Mempunyai kewajiban yaitu memberikan pelayanan jasa yang, tidak membahayakan keselamatan dan keamanan untuk konsumen. Dan pelaku usaha mendapatkan keuntungan ekonomis daripada hasil pengobatan tradisional dibidang pelayanan kesehatan.

Pelayanan yang diberikan kepada konsumen Pelaku usaha pengobatan tradisional harus dapat dipertanggungjawabkan sesuai dengan norma agama dan budaya masyarakat. Penyehat tradisional yaitu sebutan bagi pelayanan kesehatan tradisional harus memenuhi persyaratan yang telah ditentukan oleh Peraturan perundang-undangan. Dalam setiap pelayanan yang diberikan harus benar-benar memberi perlindungan khususnya bagi konsumen jasa.

Pelaku usaha dalam bidang pengobatan tradisional sangat diperlukan bagi konsumen jasa yang menggunakannya. Namun didalam Undang-undang Kesehatan belum mengatur secara jelas mengenai tanggung jawab tersebut khususnya penyehat tradisional. Ada perbedaan dengan UU Perlindungan Konsumen yang telah jelas mengatur tentang hak-dan kewajiban bagi konsumen dan pelaku usaha. Ini membuktikan bahwa adanya kemajuan dalam melindungi pihak-pihak pada kegiatan ekonomi.

Serang pelaku usaha terikat untuk memperhatikan apa yang menjadi hak-hak dari konsumen. Tanggung jawabnya atas produk yang merugikan konsumen dapat berupa penggantian dengan barang dan/atau jasa yang sama dan penggantian atau dengan sejumlah uang.

Konsumen paling banyak mengalami kerugian yang disebabkan produk dari pelaku usaha itu sendiri. Yang disebabkan karena pelaku usaha mempunyai posisi yang lebih kuat dibanding konsumen. Saat konsumen sudah memenuhi kewajibannya seharusnya pelaku usaha memenuhi hak dari konsumen. Dengan memberikan pelayanan jasa di bidang pengobatan tradisional yang aman, tidak membahayakan jiwa bagi konsumen. Apabila pengobat tradisional lalai dan merugikan konsumen, maka semestinya bertanggung jawab. Pada pengobatan tradisional ini ,biasanya cukup dengan perjanjian lisan. Terdapat perbrdaan dengan pelayanan kesehatan di Rumah Sakit, adanya perjanjian tertulis pada setiap tindakan operasi,tuntuk dijadikan sebagai alat bukti jika sewaktu-waktu adanya terjadi malapraktik oleh pihak dokter. Secara yuridis pasien tidak dapat diindentikkan dengan konsumen, hal ini karena hubungan yang terjadi diantara mereka bukan merupakan hubungan jual beli. Melainkan hubungan antara dokter dan pasien yang merupakan bentuk perikatan medis yaitu perjanjian usaha tepatnya perjanjian usaha kesembuhan (terapeutik). 
Produsen atas produk yang dapat merugikan konsumen perlu diperhatikan dan perhatian dari pemerintah yang berwenang demi tercapainya kepuasan konsumen dan keuntungan dari para pelaku usaha.

\section{PENUTUP}

\section{A. Kesimpulan}

Dari uraian dan analisis pada bab terdahulu, berikut disajikan kesimpulan yang merupakan jawaban terhadap permasalahan dalam penelitian ini, yaitu:

1. Pengaturan perlindungan hukum bagi penyehat pada pengobatan tradisional empiris diatur dalam UU Kesehatan, Peraturan Pemerintah mengenai Pelayanan Kesehatan Tradisional, serta Peraturan Menteri Kesehatan tentang Pelayanan Kesehatan Tradisional Empiris. Akan tetapi dalam prakteknya, para penyehat tradisional empiris belum mendapatkan perlindungan hukum yang diharapkan. Meningkatnya pemanfaatan layanan kesehatan tradisional tentu saja perlu dibarengi dengan kajian penguatan hukum terhadapnya. Perannya sebagai salah satu tenaga kesehatan masyarakat perlu didorong perannya. Selain isu keamanan dan keselamatan konsumen, seorang pengobat tradisional perlu mendapatkan perlindungan hukum terhadap profesinya. Perubahan peristilahan dari Pengobatan tradisional ke Penyehat Tradisional terkait erat dengan persepsi birokrasi yang terlihat dalam PP No. 103 Tahun 2014 yang menginginkan adanya perbedaan yang tegas antara pengobatan moderen yang telah mempunyai struktur yang jelas baik dari segi keanggotaan, pengaturan dan controlling keanggotaan internal, pengorganisasiannya maupun etika profesi dari perilaku sampai pada tindakan profesi.

2. Peran Pemerintah Daerah Kabupaten Semarang dalam melaksanakan wewenangnya menerapkan aspek perlindungan hukum bagi penyehat pengobatan tradisional empiris dapat dikaji dari fungsi pemerintahan berdasarkan perlindungan secara hukum. Ada tiga macam bentuk perlindungan hukum pemerintah yaitu sebagai pembuat undang-undang, pelaksana undang-undang dan sebagai pengawas undang-undang. Sebagai pembuat undang-undang, pemerintah berwenang membuat suatu peraturan yang mengatur dengan konkrit mengenai pelayanan kesehatan tradisional. UU Kesehatan mengatur bidang kesehatan secara menyeluruh tapi tidak spesifik dalam mengatur pelayanan bidang kesehatan tradisional. Pengaturan yang lebih khusus diatur dalam Peraturan Pemerintah tentang Pelayanan Kesehatan Tradisional sebagai peraturan pelaksana UU Kesehatan. Sedangkan kewenangan pemerintah dalam hal pelaksanaan lebih diarahkan kepada pelaksanaan pelayanan kesehatan tradisional itu sendiri. Misalnya dalam pemberian izin praktik pelayanan kesehatan tradisional kepada tenaga kesehatan tradisional. Kewenangan pemerintah sebagai penegak undang-undang lebih dilakukan dalam memberikan sanksi apabila terjadi pelanggaran hukum. Ada dua jenis sanksi yaitu sanksi pidana dan sanksi administratif. Sanksi pidana akan diberikan apabila penyehat tradisional maupun tenaga kesehatan tradisional melakukan kelalaian sehingga menyebabkan pasien atau kliennya mengalami suatu kerugian atau bahkan kematian. Sedangkan sanksi administratif diberikan apabila penyehat tradisional maupun tenaga kesehatan tradisional tidak memenuhi standar 
pelayanan seperti standar pendidikan, standar kompetensi, standar operasional prosedur atau kode etik profesi.

3. Pelayanan Kesehatan Tradisional dalam menjalankan kegiatannya dengan tujuan untuk mengobati atau menyembuhkan orang sakit, tidak menutup kemungkinan untuk mencari manfaat ekonomis pula. Jadi secara umum penyedia jasa pelayanan kesehatan tradisional dapat dikatakan sebagai pelaku usaha yang bergerak dalam bidang pelayanan jasa kesehatan, yaitu pelayanan kesehatan tradisional. Peraturan Pemerintah ini hanya memberikan ijin pada satu keahlian saja pada penyehat pengobatan tradisional empiris. Inilah yang membuat dilema dan yang mengganjal di hati para penyehat tradisional. Pengobat pada pelayanan kesehatan tradisional harus memenuhi persyaratan yang telah ditentukan oleh Peraturan perundangundangan. Disetiap pelayanan yang diberikan harus benar-benar memberi perlindungan bagi konsumen jasa. Pelaku usaha pengobatan tradisional sangat diperlukan bagi konsumen jasa yang menggunakannya. Namun UU Kesehatan belum mengatur secara jelas mengenai tanggung jawab pelaku usaha khususnya penyehat tradisional. Ada berbedaan dengan UUPK yang telah jelas mengatur tentang hak-dan kewajiban bagi konsumen dan pelaku usaha. Ini membuktikan bahwa adanya kemajuan dalam melindungi pihak-pihak pada kegiatan ekonomi.

\section{DAFTAR PUSTAKA}

\section{Buku/Literatur}

A. Gunawan Setiardja, 2003, Dialektika Hukum dan Moral Dalam Pembangunan Masyarakat Indonesia, Yogyakarta: Kanisius

Agnes Widanti, et al, 2009. Petunjuk Penulisan Usulan Penelitian Dan Tesis. Semarang: Magister Hukum Kesehatan, Fakultas Pascasarjana Unika Sogiejopranata

Andi Hamzah, 2005, Kamus Hukum, Jakarta: Ghalia Indonesia

Azwar Agoes, et.al, 1998, Antropologi Kesehatan Indonesia Jilid 1, Jakarta: Penerbit Buku Kedokteran

Azwar Saifuddin, 2004, Teori dan Pengukurannya, Yogyakarta: Liberty

Depkes RI, 2009, Sistem Kesehatan Nasional, Jakarta

E. Saefullah Wirapradja, 1989, Tanggung jawab Pengangkut dalam Hukum Udara Internasional dan Nasional, Yogyakarta: Liberty

E. Suherman, 1976, Masalah Tanggungjawab pada chenter Pesawat Udara dan Beberapa Masalah lain dalam Bidang Penerbangan, Bandung: Alumni

Jimly Asshiddiqie dan M. Ali Safa"at, 2006, Teori Hans Kelsen Tentang Hukum, Jakarta: Sekretariat Jenderal \& Kepaniteraan Mahkamah Konstitusi RI

John M. Echols dan Hassan Shadily, 1997, Kamus Indonesia Inggris, Jakarta: Gramedia

Kementerian Kesehatan Republik Indonesia, 2012, Profil Kesehatan Indonesia Tahun 2012, Jakarta: Kementerian Kesehatan Republik Indonesia

Miriam Budiarjo, 1998, Dasar-Dasar Ilmu Politik, Jakarta: Gramedia 
NHT Siahaan, 2005, Hukum Konsumen, Perlindungan Konsumen dan Tanggung Jawab Produk, Jakarta: Panta Rei

Paulus E. Lotulung, 1993, Beberapa Sistem tentang Kontrol Segi Hukum terhadap Pemerintah, Bandung: Citra Aditya Bakti

Ridwan HR, 2002, Hukum Administrasi Negara, Yogyakarta: UII Press

Ridwan HR, 2006, Hukum Administrasi Negara, Jakarta: Raja Grafindo Persada

Ryas Rasyid, t.th., Desentralisasi Dalam Menunjang Pembangunan Daerah Dalam Pembangunan Administrasi Di Indonesia, Jakarta: LP3ES

Shidarta, 2004, Hukum Perlindungan Konsumen Indonesia, Jakarta: PT. Gramedia Widiasarana Indonesia

Sjachran Basah, 1992, Perlindungan Hukum atas Sikap Tindak Administrasi Negara, Bandung: Alumni

Soekidjo Notoatmodjo, 2003, Pendidikan dan Perilaku Kesehatan, Jakarta: PT. Rineka Cipta , 2010, Etika dan Hukum Kesehatan, Jakarta: Rineka Cipta

Sudikno Mertokusumo, 1996, Mengenal Hukum, Suatu Pengantar, Yogyakarta: Liberty

Suharsimi Arikunto, 1998, Metode Penelitian (Pendekatan Penelitian), Jakarta: Rineka Cipta

Titik Triwulan dan Shinta Febrian, 2010, Perlindungan Hukum bagi Pasien, Jakarta: Prestasi Pustaka

W. Riawan Tjandra, 2008, Hukum Administrasi Negara, Yogyakarta: Universitas Atma Jaya

WHO, 2009, Manajemen Pelayanan Kesehatan Primer, Ed.2, Jakarta: Penerbit Buku Kedokteran

Wahyu Sasongko, 2007, Ketentuan-Ketentuan Pokok Hukum Perlindungan Konsumen, Bandar Lampung: Penerbit Universitas Lampung

\section{Peraturan Perundangan}

RI Undang-Undang Tahun 1945

RI Undang-Undang Nomor 8 Tahun 1999 tentang Perlindungan Konsumen

RI Undang-Undang Nomor 36 Tahun 2009 tentang Kesehatan

RI Undang-Undang Nomor 23 Tahun 2014 tentang Pemerintahan Daerah

RI Peraturan Pemerintah Nomor 103 Tahun 2014 tentang Pelayanan Kesehatan Tradisional

Peraturan Menteri Kesehatan Nomor 61 Tahun 2016 tentang Pelayanan Kesehatan Tradisional Empiris 
Keputusan Bupati Kabupaten Semarang Nomor 130/0440/2017 Tentang Pendegelasia Sebagian Kewenangan Bupati Semarang Kepada Kepala Dinas Penanaman Modal Dan Pelayanan Terpadu Satu Pintu Kabupaten Semarang Untuk Menertibkan Dan Menanda Tangani Perizinan Dan Non Perizinan, Serta Penandatanganan Kerjasama Terkait Dengan Pengelolaan Reklame

\section{Jurnal/Makalah}

Dewi Andika Rahayu,2012, Faktor-Faktor yang Berhubungan dengan Pemilihan Pengobatan Tradisional di Wilayah Kerja Puskesmas Muara Siberut Kecamatan Siberut Selatan Kabupaten Kepulauan Mentawai Tahun 2012. Mentawai.[Jurnal]. Padang: Fakultas Kesehatan Masyarakat

Isrok, 2005, Wewenang DPRD Dalam Pemilihan Kepala Daerah Berkaitan Dengan Pemilihan Langsung, Disertasi, Malang: Program Pascasarjana Universitas Brawijaya

Mailinda Eka Yuniza, 2013, Pengaturan Pelayanan Kesehatan Di Kota Yogyakarta Setelah Penerapan Otonomi Luas, Mimbar Hukum Volume 25, Nomor 3, Oktober 2013

Malik, 2007, Perspektif Fungsi Pengawasan Komisi Yudisial Pasca Putusan Mahkamah Konstitusi, Tesis tidak diterbitkan, Malang: Program Pascasarjana Universitas Brawijaya

Masitah Effendi, 2012, Pemanfaatan Sistem Pengobatan Tradisional (BATTRA) di Puskesmas Gundih Surabaya. [Skripsi]. Surabaya: Fakultas Ilmu Sosial Ilmu Politik Universitas Airlangga

Philipus M. Hadjon dalam Malik, 2007, Perspektif Fungsi Pengawasan Komisi Yudisial Pasca Putusan Mahkamah Konstitusi, Tesis tidak diterbitkan, Malang: Program Pascasarjana Universitas Brawijaya

Radhitya Widyasworo, 2014, Analisis Pengaruh Pendidikan, Kesehatan, Dan Angkatan Kerja Wanita Terhadap Kemiskinan Di Kabupaten Gresik (Studi Kasus Tahun 2008 - 2012), Jurnal Ilmiah, Malang: Fakultas Ekonomi Dan Bisnis Universitas Brawijaya

\section{Internet}

Definisi Sehat, diakses dari http://id.answers.yahoo.com/question/ index?qid= 20081223210437AAnxc70, 14 Agustus 2017

Konsep Sehat-Sakit, diakses dari http://www.tugaskuliah.info/2009/ 10/bahan-kuliahkonsep-sehat-sakit, 14 Agustus 2017

Layanan Tradisional Diterapkan di 70 RD. http://pointingonline.com/2014-layanantradisional-diterapkan-di-70-rs/ diakses 25 Agustus 2017 